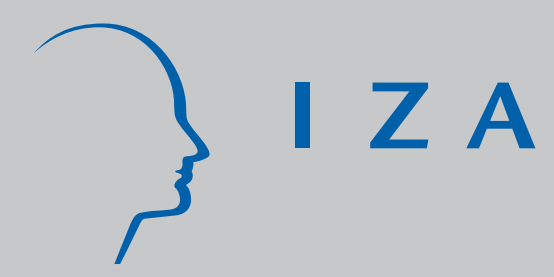

IZADP No. 2859

Imperfect Transmission of Tacit Knowledge and Other Barriers to Entrepreneurship

Vesa Kanniainen

Panu Poutvaara

J une 2007 


\title{
Imperfect Transmission of Tacit Knowledge and Other Barriers to Entrepreneurship
}

\author{
Vesa Kanniainen \\ University of Helsinki \\ Panu Poutvaara \\ University of Helsinki and IZA
}

Discussion Paper No. 2859

June 2007

IZA
P.O. Box 7240
53072 Bonn
Germany

Phone: +49-228-3894-0

Fax: +49-228-3894-180

E-mail: iza@iza.org

\begin{abstract}
Any opinions expressed here are those of the author(s) and not those of the institute. Research disseminated by IZA may include views on policy, but the institute itself takes no institutional policy positions.
\end{abstract}

The Institute for the Study of Labor (IZA) in Bonn is a local and virtual international research center and a place of communication between science, politics and business. IZA is an independent nonprofit company supported by Deutsche Post World Net. The center is associated with the University of Bonn and offers a stimulating research environment through its research networks, research support, and visitors and doctoral programs. IZA engages in (i) original and internationally competitive research in all fields of labor economics, (ii) development of policy concepts, and (iii) dissemination of research results and concepts to the interested public.

IZA Discussion Papers often represent preliminary work and are circulated to encourage discussion. Citation of such a paper should account for its provisional character. A revised version may be available directly from the author. 
IZA Discussion Paper No. 2859

June 2007

\section{ABSTRACT \\ Imperfect Transmission of Tacit Knowledge and Other Barriers to Entrepreneurship}

This paper identifies several distortions which create barriers to entrepreneurship. First, in addition to the innate entry cost, there are entry costs caused by regulation. Second, union wage policies raise the opportunity cost of entrepreneurship. Third, inefficiencies in the transmission of tacit knowledge between generations of entrepreneurs can arise: with access to within-family ownership transfer, the outside market for entrepreneurship operates as a lemon's market. This problem becomes relevant when the economic life of a business idea exceeds the active life of an entrepreneur.

JEL Classification: J24, $\mathrm{H} 25$

Keywords: barriers to entrepreneurship, tacit knowledge, occupational choice

Corresponding author:

Panu Poutvaara

Department of Economics

University of Helsinki

P.O. Box 17 (Arkadiankatu 7)

FIN-00014 Helsinki

Finland

E-mail: panu.poutvaara@helsinki.fi 


\section{Introduction}

Entrepreneurship is the driving force in the economic success of countries. Many empirical studies suggest that the measured rate of entrepreneurship relative to the total labor force of an economy typically falls within, say 6-10 per cent. ${ }^{1}$ Abstracting from self-employment, the rate of entrepreneurship proper (those who employ workers) is much smaller. To develop policies towards entrepreneurship, it is important to identify the barriers in the market for entrepreneurship to alleviate the effects of those distortions. The current paper discusses several of those mechanisms. A model of occupational choice is developed to cope with a number of issues.

Earlier papers have pointed to entry costs or taxes in shaping the market entry of start-up firms. The work on entry-related regulatory costs by Djankov, La Porta, Lopez-de-Silanes and Shleifer (2001), in particular, suggests that these costs are empirically significant. ${ }^{2}$ Our paper qualifies the role of entry costs. This is one of the topics addressed. We suggest that people differ substantially in terms of their ability to produce a business idea, elaborate their idea and make its way to a marketable product or service. From the perspective of the public finance theory, such costs represent innate social costs which do not necessarily justify policy interventions. However, the entry costs caused by, say excessive governmental regulation, do. ${ }^{3}$ The second distortion addressed by our paper arises from labor markets where rent-seeking unions defend the interests of special groups with their bargaining power on wages. Such behavior raises the opportunity cost of entry for a potential entrepreneur. It also has an impact on the firm's labor demand and hence the size distribution of firms. Both effects interfere with the for-

\footnotetext{
${ }^{1}$ Ilmakunnas and Kanniainen (2001).

${ }^{2}$ The estimated entry cost, including the number of procedures on safety and health, environment, taxes, labor, screening and the monetized value of the entrepreneurs' time is low in Canada and the USA, i.e., 2.3 and 1.7 per cent relative to GDP per capita. It is much higher in the European economies, 32.5 per cent in Germany and 44.8 per cent in Italy, for example. In Ireland, the entry cost is lower than in the continental Europe, 18.9 per cent, which has led to substantial gains in enterprise formation. Some care is needed in the interpretation of data. For example, while in the high-entry-regulation Italy, the entry cost is relatively high, the rate of measured entrepreneurship is also high because of the high rate of self-employment. Moreover, firms start out larger when young in Italy, but grow more slowly (Klapper, Laeven and Rajan (2006)).

${ }^{3}$ This argument is based on the empirical observations that some countries have been much more successful than others in economizing on those costs cf. Djankov et al. (2002).
} 
mation of entrepreneurship in an economy. ${ }^{4}$ Finally, the life of a business idea may be much longer than is the working life. Retiring entrepreneurs seek successors. From the social point of view, the efficient transmission of the tacit knowledge accumulated by an active entrepreneur would be highly desirable. Frictions in the market for firms and the risk of winner's curse create informational barriers. The successors cannot judge the value of the tacit knowledge available. We introduce an analysis of overlapping generations of entrepreneurs which, we think, is new.

The influential proposition by De Meza and Webb (1987, 1999), elaborated subsequently by Boadway and Keen (2006), suggests that the social value of the marginal entrepreneur when financed from outside sources is negative. The policy implication is fierce: a tax on start-up entrepreneurs increases welfare. The proposition has been gained additional support from the paper by Coelho, De Meza and Reyniers (2004) who claim that people in general and entrepreneurs in particular are overly optimistic. The policy implication of this latter view is even more dramatic: a tax on entrepreneurs enhances not only the social welfare but also the private welfare of the marginal entrepreneur. Our claim is that these papers have focused just on one or two distortions, that arising from informational asymmetry in the credit markets or excessive optimism. They have, however, abstracted from other equally (or even more) relevant distortions to be discussed in the current paper. ${ }^{5}$ For example, the De Meza - Webb proposition was formulated for self-employed entrepreneurs. Entrepreneurs employing outside labor will bear - jointly with those becoming unemployed - the burden created by the labor market distortions.

We noticed above that there is a real problem of how to measure empirically entrepreneurship. The data is also convincing that self-employment is the strongest in developing countries. Due to high entry costs and hence nonexisting firms, people become self-employed "entrepreneurs" to make their living. In industrialized economies with high unemployment, there is push towards entrepreneurship, particularly in the peripheral areas with high un-

\footnotetext{
${ }^{4}$ Kanniainen and Leppämäki (2005) suggest that union wage policies enhance the entrepreneurial risk, discouraging entry. Kanniainen and Vesala (2005) suggest that various labor protection measures have the same effect. Such conclusions obtain indirect support from the European experience where the development of entrepreneurship has been quite disappointing for quite some time.

${ }^{5}$ Recently, Puri and Robinson (2006) using the data in Survey of Consumer Finance have downplayed the proposition of excessive optimism of entrepreneurs.
} 
employment and few firms. A tax proposed by the De Meza - Webb model on those self-employed "entrepreneurs" would be devastating.

Our paper introduces a unified and technically easy model to analyze the stated issues. The framework is flexible and we extend it in several directions. Some additional extensions are included as concluding remarks in the final section. ${ }^{6}$

\section{Entrepreneurship and Labor Markets}

\subsection{Competitive Labor Markets}

In our model, the economy is assumed to consist of a continuum of one-period lived individuals with mass one. All capital is entrepreneurial capital. There is no physical capital. ${ }^{7}$ Each individual can either become a worker or an entrepreneur who employs some workers. We do not consider the self-employed. In the technology considered, both an entrepreneur and a worker are necessary inputs. Entrepreneurs create the jobs and manage them. Workers make firms productive. All people are alike by their productivity as workers but they differ in terms of their entrepreneurial skills. ${ }^{8}$ It is convenient to differentiate people according to their entry costs (ability) as entrepreneurs. In particular, setting up an enterprise involves fixed start-up costs of two types. The first type, $c^{i}$, is individual-specific and unobservable. It is uniformly distributed on $[0, \bar{c}]$. High-ability entrepreneurs face a lower entry cost than the low-ability ones. The second type, $\widehat{c}$, arises from government regulation. Both become sunk. Demand is perfectly elastic at price $p$.

\footnotetext{
${ }^{6}$ The effects of entrepreneurial, capital and labor taxes on entry of start-up firms have been analyzed in Kanniainen, Kari and Ylä-Liedenpohja (2007). We largely abstract from taxes in the current paper. We point, however, that the innate entry costs are largely unobservable and hence do not qualify as deductible expenses in the income tax base of an entrepreneur. This raises the effective income tax on a start-up firm. There is some research on the effects of redistributive taxation on occupational choices. Boadway et al. (1991) analyze a discrete occupational choice between a risky and a safe occupation, where citizens differ ex ante. Poutvaara (2002) analyzes the effects of taxation on a choice between several risky occupations, deriving the conditions under which redistributive taxation encourages risk-taking.

${ }^{7}$ Our model is basically an extension of Kanbur (1979) to incorporate the entry cost. The model can easily be extended to include productive capital.

${ }^{8}$ This important distinction has been conventional since Lucas (1978).
} 
Occupational choice. We assume that the utilities are linear in income, labor markets are competitive and there is thus one wage rate. In the basic model, there is no entrepreneurial risk. ${ }^{9}$ Entrepreneurs hire workers who provide a unit input at the market wage and produce the output. Each worker produces one unit of output. Additional labor hires lead to increasing costs. Thus, the technology has a "U-shaped" average cost curve. Entrepreneurs earn the residual profit. It is convenient to model the technology and the resulting profit of entrepreneur $i$ as

$$
\pi^{i}=-\left(\widehat{c}+c^{i}\right)+p l-w l-w \frac{1}{2} l^{2} .
$$

The labor demand (size) of each firm, $l(w)$, is solved from $\max _{l} \pi^{i}$ as

$$
l=\frac{p-w}{w} .
$$

Let $v$ denote the size of the entrepreneurial class. Labor market equilibrium

$$
1-v=v l
$$

then determines the market-clearing wage. To solve for it, insert $l=\frac{p-w}{w}$ to obtain the solution for the wage, $w(v)$, in terms of the size of the entrepreneurial class, $v$

$$
w=v p .
$$

Thus, firm size (labor demand) becomes

$$
l=\frac{1-v}{v} .
$$

The marginal entrepreneur, $m$, is just indifferent between setting up an enterprise and entering as a worker,

$$
-\left(\widehat{c}+c^{m}\right)+p l-w l-w \frac{1}{2} l^{2}=w .
$$

This condition will be repeatedly used in the current paper.

From the distribution of the start-up costs, the marginal entrepreneur's cost is given by

$$
c^{m}=v \bar{c} .
$$

\footnotetext{
${ }^{9}$ We introduce the failure risk below.
} 
Thus, inserting $w$ and $l$, we re-write the indifference condition of the marginal entrepreneur as

$$
-(\widehat{c}+v \bar{c})+p \frac{1-v}{v}-v p \frac{1-v}{v}-v p \frac{1}{2}\left(\frac{1-v}{v}\right)^{2}-v p=0 .
$$

This simplifies to a second-order equation in $v$, the size of the entrepreneurial class,

$$
v^{2}[(2 / p) \bar{c}+1]+[(2 / p) \widehat{c}+2] v-1=0 .
$$

Solving, we obtain

Proposition 1 The size of the entrepreneurial class is determined by

$$
v=\frac{\sqrt{[(1 / p) \widehat{c}+1]^{2}+[(2 / p) \bar{c}+1]}-[(1 / p) \widehat{c}+1]}{[(2 / p) \bar{c}+1]} .
$$

Because $\partial \nu / \partial \bar{c}<0, \partial \nu / \partial \widehat{c}<0$, both entry costs operate like a tax entrepreneurship.

The government's failure to economize on the bureaucratic costs and other consequences of excessive regulation results in reduced enterprise formation. ${ }^{10}$ Having stated this conclusion and to economize on notations, we simplify the formal model making $\widehat{c}=0$. Then we have

$$
v=\frac{\sqrt{1+[(2 / p) \bar{c}+1]}-1}{[(2 / p) \bar{c}+1]} .
$$

Entrepreneurial risk So far we have abstracted from the failure risk of an entrepreneur. We now introduce the risk. ${ }^{11}$ Denoting $\theta=$ the probability

\footnotetext{
${ }^{10}$ This problem is serious particularly in many developing countries with wide corruption.

${ }^{11}$ The failure rate of new enterprises indeed is substantial. A German study suggested that 24 per cent of German start-up firms were closed down within the first two years and 37 per cent within the five first years (Bruderl, Preisendorfer and Ziegler (1992)). In the UK, 45 per cent of new start-up firms were closed down within the first two and a half years and 80 per cent within six years (Cressy, 1996, 2006). In Portugal, 20 per cent of new firms fell within the first year and 50 per cent within the first four years (Mata and Portugal (1994)).
} 
of success and $1-\theta=$ the probability of failure, the expected profit is stated as

$$
\pi^{i}=-c^{i}+\theta p l-w l-w \frac{1}{2} l^{2} .
$$

The entrepreneur faces an unlimited liability. With the failure risk introduced, the size of the entrepreneurial class is determined by

$$
v=\frac{\sqrt{1+[(2 / \theta p) \bar{c}+1]}-1}{[(2 / \theta p) \bar{c}+1]} .
$$

The natural conclusion follows that reduced failure risk (increase in $\theta$ ) increases the size of the entrepreneurial class, $\partial v / \partial \theta>0$; the marginal entrepreneur can afford to incur a smaller cost of entry. Having stated this result, we resume back to the basic model where $\theta=1$.

Incidence. To study the incidence of entry cost, recall that the equilibrium market wage is given by $w=v p$. Thus, $\partial w / \partial \bar{c}=p \partial v / \partial \bar{c}<0$. Therefore, as the entry cost reduces entrepreneurship, its effect is capitalized in the market wage $w=v p$.

Corollary 1. The entry cost of entrepreneurs is capitalized in the market wage of workers.

Another consequence, however, is that the size of each enterprise is bigger when the entry cost is high, as $\partial l / \partial v=\partial\left(\frac{1-v}{v}\right) / \partial v<0 .{ }^{12}$

It is typical to argue in our profession that wages are linked to productivity. We do not challenge this proposition but we provide a complementary angle: wages are low because the entry costs as an entrepreneur are high for most people.

The (first-best) social welfare (total income) is given by the value-added (wages + profits)

$$
W=v u_{e}+(1-v) u_{w}=v \pi+(1-v) w .
$$

The social value of an entrepreneur is measured by the profit he is generating. However, this measure should not obscure the mechanism that by setting up a firm which employs workers, the workers employed have access to positive inframarginal benefits measured by the cost saving as they need

\footnotetext{
${ }^{12}$ We notice that our model thus confirms what the data suggested of the high-entryregulation Italian case above.
} 
not enter as entrepreneurs. Someone else is employing them (and taking the risk). The entrepreneurs are compensated for their social contribution in terms of their profit. Entrepreneurs with low entry costs earn positive rents. In equilibrium, the marginal entrepreneur's utility equals that of the workers.

\section{Labor Unions}

We next consider the case where the assumption of a competitive labor market is replaced by the assumption that the wage rate is determined by a union. The union solution results in a market wage which exceeds the competitive wage derived above ${ }^{13}$,

$$
\bar{w}>w .
$$

In Europe, unions are typically industry-wide and sometimes the wage negotiations determine the wage development also at the national level. ${ }^{14}$ As workers have the same productivity, there is no role for differentiated wages. Instead, the union chooses the wage rate to maximize its objective function. ${ }^{15}$

At a higher wage, each enterprise employs less workers as $l^{\prime}(w)<0$ and labor demand is

$$
l=\frac{p-\bar{w}}{\bar{w}} .
$$

Labor market equilibrium is distorted away from the competitive equilibrium. If there are $n$ unemployed workers, the number of employed workers $v l$ satisfies

$$
1-v-n=v l
$$

or

$$
n=1-v(1+l) .
$$

Inserting $1+l=\frac{p}{w}$, unemployment is determined as

$$
n=1-v \frac{p}{\bar{w}} .
$$

\footnotetext{
${ }^{13}$ Cf. Oswald (1985) and Farber (1986).

${ }^{14}$ France is an example of country where the formal union coverage among workers is limited but where the union wages are yet largely adopted in the economy. In the high union density countries like Finland and Sweden, the wage negotiations have often been nationwide.

${ }^{15}$ Consequently, the unemployment rate tends to higher in a unionized economy when compared with economies with a more limited union power, ch. Nickel (1997). This creates an interest conflict - known as an insider/outsider conflict - between the employed workers and those who end up collecting unemployment compensation.
} 
The greater $\bar{w}$ is, the greater is unemployment.

What about the entry condition of a start-up entrepreneur in a unionized economy? For the marginal worker among those who have the option of being employed by some entrepreneur, the entry condition is ${ }^{16}$

$$
-c_{u}^{m}+p l-\bar{w} l-\bar{w} \frac{1}{2} l^{2}=\bar{w} .
$$

We have denoted the entry cost of the marginal entrepreneur in a unionized economy by $c_{u}^{m}$. It must be lower than in the case of a competitive labor market, $c_{u}^{m}<c^{m}$.

Introducing $l=\frac{p-\bar{w}}{\bar{w}}$,

$$
-c_{u}^{m}+p\left(\frac{p-\bar{w}}{\bar{w}}\right)-\bar{w}\left(\frac{p-\bar{w}}{\bar{w}}\right)-\bar{w} \frac{1}{2}\left(\frac{p-\bar{w}}{\bar{w}}\right)^{2}-\bar{w}=0,
$$

or

$$
-c_{u}^{m}+\frac{1}{2}(p-\bar{w})^{2}\left(\frac{1}{\bar{w}}\right)-\bar{w}=0 .
$$

Insert $c_{u}^{m}=v_{u} \bar{c}$, where $v_{u}<v$ denotes the entrepreneurship in the unionized economy, we can solve

$$
v_{u}=\frac{(p-\bar{w})^{2}-2 \bar{w}^{2}}{2 \overline{c w}}
$$

We state

Proposition 2 Union wage setting reduces entrepreneurship, making the size of the entrepreneurial class deviate from its first-best level. ${ }^{17}$

The condition $v_{u}<v$ is satisfied when it holds that

$$
v_{u}=\frac{(p-\bar{w})^{2}-2 \bar{w}^{2}}{2 \overline{c w}}<v=\frac{\sqrt{1+[(2 / p) \bar{c}+1]}-1}{[(2 / p) \bar{c}+1]} .
$$

\footnotetext{
${ }^{16}$ This formulation assumes that the union wage represents the opportunity cost to those who could become entrepreneurs.

${ }^{17}$ Some econometric support is available for our proposition. Using OECD country data in 1978-93, Ilmakunnas and Kanniainen (2001) find a negative relationship between entrepreneurship and union density. In Kanniainen and Vesala (2005) using extended OECD data set for 1978-98, the union effect is measured by several variables. All those variables obtain negative coefficients as predicted by their model. Taken together, this evidence indicates that union power reduces the entry of new enterprises, as suggested by our model.
} 
A simple numerical example demonstrates. Take that $p=\bar{c}=1$. Then, $v=\frac{1}{3}$ and $w=\frac{1}{3}$. Make the union wage marginally higher, say $\bar{w}=\frac{1.1}{3}$. Then solving for the entrepreneurship in the unionized economy gives $v_{u}=0.13<$ $\frac{1}{3}$.

\section{Tacit Knowledge and Enterprise Turnover: An Overlapping Generations Approach}

We now introduce formally the idea that entrepreneurs (and workers) live two periods. The first period is spent as a worker or as an entrepreneur and the second period as a retiree. A firm can be established as a start-up by a new entrepreneur or it can be bought from a retiring entrepreneur. In the previous sections, we assumed that each firm is active for one period and then is terminated. Now we introduce an assumption that enterprises can be traded at the end of the life-cycle of the retiring entrepreneurs. The benefit of the option of buying an enterprise is strengthened by the possibility of acquiring at the same time valuable tacit knowledge from the retiring entrepreneur who in turn acquired his knowledge during his business life. The tacit knowledge is imbedded in an entrepreneur. Therefore, its quality cannot be observed nor contracted upon.

In our model, there is no physical capital. The firm's market value thus completely reflects the perceived tacit knowledge to be traded. Access to such knowledge would enhance the profitability of the enterprise for the new entrepreneur. The new entrepreneur, however, faces an informational problem: he cannot judge ex ante the value of the advice delivered. The informational asymmetry may create a discontinuity in transition of entrepreneurial knowledge from one generation of entrepreneurs to the next one and gives rise to some challenging policy issues. ${ }^{18}$

In each period $t$, there are retiring entrepreneurs from period $t-1$ and the new ones. They stand willing to help and advise the new entrepreneur providing him with their tacit knowledge. There are several issues. How is the tacit knowledge priced? In which way is it transmitted?

We assume that the value of knowledge is related to the entrepreneurial

\footnotetext{
${ }^{18}$ There is a further informational barrier in the market for firms: how to locate the retiring entrepreneurs and match them with potential new entrepreneurs? This issue can be addressed by a search model though we do not take it up in this paper.
} 
ability of the retiring entrepreneur. Those who turned out to face a low entry cost are good candidates of providing high-quality advice while those with a larger entry cost can provide an advice of lower quality. The abilities of the new entrepreneurs to absorb the knowledge are not differentiated, only their entrepreneurial skill reflected in the entry cost is.

The true quality of advice, $q$, can then be modeled as

$$
q^{i}=\bar{c}-c^{i}
$$

We use $\mu^{i}$ to denote the price of the advice. With perfect information,

$$
\mu^{i}=q^{i}
$$

The informational asymmetry concerns the unobservability of quality $q$. As the start-up cost $c^{i}$ is unobservable, the entrepreneurs' income statement does not provide information on the entrepreneurial ability. This is the information barrier we analyze below. We take it for granted that the retiring entrepreneur wants to cash in on his business. Tacit knowledge can be transmitted, however, only through a costly training effort. The time allocated by the retiring entrepreneur has its opportunity cost. We denote the cost of the training effort of the retiring entrepreneur by $C>0 .{ }^{19}$

Moreover, frictions in the market for firms can also arise from that the retiring entrepreneurs tend to attach emotional value to their business. It is not clear ex ante whether this would result in underpricing or overpricing. The retiring ones, having incurred the entry cost and spent their active life as nurturing their enterprise and business idea like their own baby, are keen to see that its life will continue. This points to the possibility of underpricing. However, with emotional attachment to their enterprise they also tend to overvalue it. In the model to be outlined here, we abstract from the emotional value.

\subsection{Equilibrium with Perfect and Symmetric Informa- tion}

It is easier first to consider the hypothetical case where the quality of advice is known to both parties. In this section, we therefore assume that the realizations of the tacit knowledge are observable and common knowledge. The

\footnotetext{
${ }^{19}$ Costly effort suggests that there also may be a moral hazard problem if the new entrepreneur is uncertain whether the retiring one really has commited to full effort. We do not explore this distortion in detail here.
} 
market for enterprises is well-functioning and the tacit knowledge is traded at its true value. Acquiring the tacit knowledge is reflected in reduced entry cost by the entering entrepreneur. His net benefit from the tacit knowledge is zero during the start-up stage. At the end of his life-cycle, he can, however, cash the knowledge he has acquired during his life-time. The tacit knowledge will thus be transferred to the next generation at the right price. The equilibrium is characterized by a distribution of consulting prices which fully reflect the quality of the advice. We suggest that access to tacit knowledge reduces the entrepreneurial threshold in an economy with perfect and symmetric information:

Lemma 1. Subject to the condition that the training cost is not too large, the entry threshold is lower in an economy where tacit knowledge is transmitted in comparison with an economy where it is not. There are more firms. As to the incidence, as wages are higher part of the welfare effect of tacit knowledge is transferred to workers.

Proof. Let $j$ denote the retiring entrepreneur and $i$ the new entrepreneur. For a formal proof, we write the entry condition of individual $i$

$$
\pi_{t}^{i}=-c^{i}+\left(q^{j}-\mu^{j}\right)+p l-w l-\frac{1}{2} w l^{2}+\max \left(0, \frac{\mu^{i}-C}{1+r}\right) \geq w,
$$

with equality sign for the marginal entrepreneur. Note that by (17), the net benefit from acquiring tacit knowledge is zero, $q^{j}-\mu^{j}=0$. We have denoted $r=$ the discount rate. The result follows provided that the condition

$$
\frac{\mu^{i}-C}{1+r}>0
$$

holds. This is the condition for the retiring entrepreneur to be active in trading his knowledge to the successor. Finally, increased labor demand raises the market wage and the incidence result is obtained. ${ }^{20}$

\subsection{Asymmetric Quality Information}

The problem which we now consider arises when the new entrepreneurs cannot verify the quality of the advise, $q$. We suggest that the new entrepreneurs

\footnotetext{
${ }^{20}$ Note that it is not the case that the current generation would be able to cash in on all future generations as those have the option of establishing a start-up firm instead of buying one.
} 
face a distribution of qualities of tacit entrepreneurial knowledge. The new ones are unable to identify the quality of the tacit knowledge. Their willingness to pay for the knowledge has to be based on the average quality of the knowledge, $\bar{q} \cdot{ }^{21}$

We now suggest that under informational asymmetry, there can be more new firms or there can be fewer new firms than under perfect information. Which case is obtained depends on whether $\frac{\bar{q}-C}{1+r}$ is positive or negative. Write the entry condition of the marginal entrepreneur as

$$
\pi_{t}^{m}=-c^{m}+p l-w l-\frac{1}{2} w l^{2}+\max \left(0, \frac{\bar{q}-C}{1+r}\right) \geq w .
$$

If $\frac{\bar{q}-C}{1+r}>0$, the low-quality entrepreneurs are able to charge more than is the true value of their tacit knowledge which they generate during their career, $\bar{q}>q^{m}$. There will be more entrepreneurs than under symmetric information. On the other hand if $\frac{\bar{q}-C}{1+r}<0$, no new entrepreneurial generation expects to be able to cash in on its tacit knowledge. There will be fewer entrepreneurs than under symmetric information.

Lemma 2. With asymmetric information of the true value of tacit knowledge, there can be more or fewer entrepreneurs than under symmetric information.

\subsection{Quality of Advice and Entrepreneurial Spirit}

At the beginning of this paper, we referred to empirical work which suggested that the entry costs differ substantially across countries. An economy with low entry cost and strong tradition in entrepreneurship in the past can be expected to have strong entrepreneurial spirit in the future. The nature of overlapping generations of entrepreneurs provides the link in this mechanism. In an economy where the marginal entrepreneur expects to benefit from the advice and tacit knowledge of the retiring entrepreneur the entry rate tends to be higher than in an economy where it is the opposite case. We can introduce this vision by adjusting the quality of advice as

$$
q^{i}(\lambda)=\bar{c}-\lambda c^{i}, \quad \lambda>0 .
$$

\footnotetext{
${ }^{21}$ The issue is analogous to the considered by DeMeza and Webb in their model of a bank. Akerlof's (1970) adverse selection model does not strictly apply here because the tacit knowledge has no alternative use.
} 
The retiring entrepreneurs in economies with a low value of $\lambda$ are able to provide higher quality advice to the start-up entrepreneurs than in those with a higher value. In the latter economy, a start-up entrepreneur buying an old firm has expected profit

$$
\pi_{t}^{i}=-c^{i}+\left(\bar{c}-\lambda c^{j}-q^{j}(\lambda)\right)+p l-w l-\frac{1}{2} w l^{2}+\frac{q^{i}(\lambda)-C}{1+r},
$$

and expects to be able to have a lower return on his consulting services than in an economy with higher $\lambda$. In an equilibrium where the tacit knowledge cannot be trusted to be valuable also workers suffer as wages are lower.

How should the government step in to eliminate the distortion? To create an economy with strong entrepreneurial spirit, the government should not only economize on entry regulation but support the creation of social capital and trust to make the transmission easier. The view emerging from our analysis points to the independent role of entrepreneurial spirit as a psychological factor in addition and above to its economic role.

\subsection{From the Parent to the Child: Regression toward the Mean}

In our analysis above, entrepreneurship was determined by self-selection with those having a low entry cost choosing entrepreneurship. The rest of the population entered the labor market. Without transmission of tacit knowledge, the resulting equilibrium repeats itself. Above we considered the case where some of the abilities useful in entrepreneurship can be transferred like a meme. In the new equilibrium, there were more entrepreneurs if such a knowledge transfer was not hampered by informational restrictions. As a result of the intergenerational transfer of tacit knowledge, the quality of the marginal entrepreneur was lower in the new equilibrium which also repeats itself.

We next consider the transmission of entrepreneurial skill within a dynasty. This issue is highly relevant as the ability of children to run the empire created by their parents has repeatedly been questioned. It is useful to make two points at the start. First and given stationarity conditions, the distribution of entrepreneurial ability of children of entrepreneurs is the same as the distribution of those skills in the whole population. However, the mean entrepreneurial ability of children must be less than the mean ability of their 
parents as entrepreneurs. This conclusion follows from regression toward the mean effect identified long ago by Galton (1886). ${ }^{22}$ Second, each parent has an informational advantage over the quality of the child when compared to outsiders. Before we consider the potential equilibria, we have to take a notice of this informational asymmetry.

\subsection{Winner's Curse in the Lemon's Market}

From the social point of view, it is important that the right people perform the right tasks in the society. The empirical results by Perez-Gonzales (2006) on the effects of inherited control on firms' performance should be brought in here. He reports that firms where incoming CEOs are related to the departing CEO, to a founder, or to a large shareholder by either blood or marriage underperform in terms of operating profitability and market-tobook ratios, relative to firms that promote unrelated CEOs. Consistent with wasteful nepotism, lower performance is prominent in firms that appoint family CEOs. In the light of those results, the parent should consider the outside offers especially if he thinks that the child is incapable. ${ }^{23}$ We consider two cases.

A competent parent A competent parent having the bequest motive transfers his firm and his tacit knowledge to the child if the child is capable. The problem of informational inefficiency is eliminated and the child's entry cost is reduced. There is, of course, the possibility that the child might make a better living, say as rock singer than as an entrepreneur, in which case he rationally refuses to continue his parent's project. The intra-dynasty transfer of tacit knowledge leads to social benefits if the transfer is more efficient within families when compared with a transfer through markets. The social optimality of the transmission within the dynasty, however, is conditional upon that no outside candidate with superior entrepreneurial quality

\footnotetext{
${ }^{22}$ It is an artifact of choosing a non-representative sample in one variable (parent having passed the demanding market test as entrepreneurs) and then examining another variable (children). See also the next reference below. What matters on average should not make one overlook the other possibility that a child might be more competent as an entrepreneur than the parent. The reason why this is less common in a large sample is the regression toward the mean effect. The successful entrepreneurs have passed the selection process.

${ }^{23}$ If the parent has several children, he may induce them to compete for their access to his enterprise.
} 
is blocked away. Moreover, although the child is less competent than an outsider candidate, the parent may transfer the firm to the child when the lemon problem results in a low market price. This is a socially costly outcome and arises when the market for firms is a lemon market.

If the bequest motive makes the parent hand the business over to his child though a better outside candidate would be available, a distortion arises and results in a welfare loss. In this case, the implication is that the transfer of business within the dynasty should be taxed. There is more to it as there are informational issues to which we now turn to.

A less competent parent Consider the case where the parent is less competent, say close the individual identified as the marginal entrepreneur. In his case, his advise to his child is of low quality and a more competent child would do better by buying another firm from the market. If the outsider is informed that the parent has a child but that the business is not transferred to the child, he rationally expects that the firm is of a low-quality type. ${ }^{24}$ The Mayers-Majluf (1984) undervaluation problem arises: the insiders know more than the outsiders. The retiring entrepreneur wants to sell at an inflated price but the rational buyers want to discount in order to avoid the winner's curse.

Distortions In terms of the efficiency criterion, we face a trade-off between two bad equilibria. There is one, where the entry cost is avoided and the tacit knowledge transferred but an incompetent child takes up the leadership. There is another one where the entry cost is not avoided and where the tacit knowledge may not be transferred. In the latter case, we are back in the problem that the outside candidate cannot judge for sure the true value of the firm.

Only low-quality enterprises - lemons - tend to be traded and the highquality ones are handed over to the children. An adverse selection problem arises. There is more to it: the parent's bequest motive may make the outcome even worse. We report

Proposition 3 When those who are outsiders to the dynasty know that the retiring entrepreneur has a child, the market value of tacit knowledge is lower

\footnotetext{
${ }^{24}$ The case may be even more complicated as is a further possibility: the outsider may be informed that the child is making a profitable career as a rock singer and concludes that the firm is not a lemon.
} 
when compared with the case where the parent has no child. There is distorted allocation of entrepreneurial talent. The low-quality firms are always brought for sale but so are the high-quality ones if the competence of the child is sufficiently low relative to the competence of the parent.

The efficiency of business turnover thus depends in an interesting way on the demographic structures of families. Access to a transfer within a dynasty may result in efficiency gains but may also hamper efficient transfers through the market. The prediction of our theory is that the market for enterprises is a lemons' market: high-quality firms are rarely sold to outsiders.

\section{Discussion}

The entry cost operates like a tax on new entrepreneurs. One can, however, argue that if it is a real social cost it should not be socialized. There is a potential counter-argument: not often but sometimes new innovations and entrepreneurs lead to unpredicted social benefits, say astronomical social returns. Just think in terms of innovative entrepreneurial superstars like Thomas Edison, Chester Carlson, Walt Disney, Steve Jobs or Bill Gates. Innovations with such extraordinary social returns also arise from innovations within companies. One can think of the social returns created by companies like Nokia and other mobile phone producers making the life so much easier for millions of people. Intrapreneurship cannot, however, fully replace entrepreneurship as those represent complementary avenues for human creativity. Given the hypothesis of complementarity and the possibility of positive social externalities unrecognized by the innovators, the De Meza-Webb tax could be rather harmful.

Part of the entry cost is caused by the excessive government regulation. The regulation itself may be needed and desirable but over-regulation creates a substantial social cost by hampering entry of new firms. As to the labor markets, while one can think that the Boadway-Keen model - implicitly captures the union effect in terms of their return variable (unions reduce the return on entrepreneurship), the model does not capture the negative externality of a monopoly union in terms of misallocation of people in various tasks in the society. Our view suggested in the current paper that the tacit knowledge is inefficiently transferred between consecutive generations because of informational asymmetries raises further issues. Tacit knowledge 
tends to be mis-priced. This is the case when the child in a dynasty is incompetent or when the outsiders consider the market for enterprises as a lemon's market. One can ask whether the De Meza - Webb tax would make things worse.

A further distortion tends to arise from the introduction of new products - which is what start-up entrepreneurs often are doing. When new products are experience goods and when the consumers are less convinced of their quality, adverse selection may take place as predicted by Akerlof (1970). Some high-quality products may not find their markets. To introduce the De Meza - Webb tax would limit entrepreneurship instead of correcting the allocation.

An income tax tends to create an entry barrier as the (unobservable) entry cost cannot qualify as a deduction in the tax base. One should also point out that a counter-mechanism is created by the possibility of successful entrepreneurs under-reporting their income and consuming private benefits in the firm. Aiming at a neutral tax treatment would require considering the total tax rate both on entrepreneurship and on its opportunity cost, the labor income. Such an analysis is still missing from public finance. We suggest that many taxes (including the cash flow tax, the dividend tax and the ACE tax) understood to be neutral with respect to the marginal investment choices of firms cannot be neutral when it comes to think about the entry of new firms (Kanniainen and Panteghini (2007)). Finally, the work on industrial organization area suggests that market entry is affected by the strategic behavior of the incumbent firms (Boadway and Trembley (2005)) and can result in additional sources of entry barriers.

\section{References}

[1] Akerlof, G. (1970), "The Market for 'Lemons': Quality Uncertainty and the Market Mechanism", The Quarterly Journal of Economics, 84, 3, 488-500.

[2] Boadway, R., Marchand, M., and P. Pestieau, P. (1991), "Optimal Linear Income Taxation in Models with Occupational Choice", Journal of Public Economics, 46, 133-162.

[3] Boadway, R. and Keen, M. (2006), "Financing and Taxing New Firms under Asymmetric Information", FinanzArchiv, 62, 471-502. 
[4] Boadway, R. and Trembley, J-F. (2005), "Public Economics and Startup Entrepreneurs", in V. Kanniainen and C. Keuschnigg, (eds.) Venture capital, Entrepreneurship, and Public Policy, CESifo Seminar Series, The MIT Press. Cambridge, Massachusetts, 181-219.

[5] Bruderl, J. Preisendorfer P. and Ziegler R. (1992), "Survival Changes of Newly Founded Business Organizations", American Sociological Review, $57,227-242$.

[6] Coelho, M., De Meza, D., and Reyniers, D. (2004), "Irrational Exuberance, Entrepreneurial Finance and Public Policy", International Tax and Public Finance, 11, 391-417.

[7] Cressy, R. (1996), “Are Business Startups Debt-rationed?", The Economic Journal, 106: 1253-1270.

[8] Cressy, R. (2006), "Why do Most Firms Die Young", Small Business Economics 26, 103-116.

[9] De Meza, D. and Webb, D. (1987), "Too Much Investment: A Problem of Asymmetric Information", Quarterly Journal of Economics, 102, 28192.

[10] De Meza, D. and Webb, D. (1999), "Wealth, Enterprise and Credit Policy", The Economic Journal, 109, 153-163.

[11] Djankov, S., La Porta, R., Lopez-de-Silanes, F., and Shleifer, A. (2002), "The Regulation of Entry", The Quarterly Journal of Economics, 117, $1-37$.

[12] Farber, H. S. (1986), "The Analysis of Union Behavior", in Handbook of Labor Economics, vol II, (eds) Ashenfelter, O. and R. Layard. NorthHolland.

[13] Galton, F., (1886), "Regression Towards Mediocrity in Hereditary Stature", Journal of Anthropological Institute, 15, 246-263.

[14] Ilmakunnas, P. and V. Kanniainen (2001), "Entrepreneurship, Economic Risks, and Risk-Insurance in the Welfare State: Results with OECD data 1978-93", German Economic Review, 2, 195-218. 
[15] Kanbur, S. M. (1979), "Of Risk Taking and The Personal Distribution of Income", Journal of Political Economy, 87, 767 - 797.

[16] Kanniainen, V. and Leppämäki, M. (2005), "Union Power, Entrepreneurial Risk and Entrepreneurship", mimeo.

[17] Kanniainen, V. and Vesala, T., (2005): "Enterprise Formation and Labor Market Institutions", Economic Modelling, 22, 828-847.

[18] Kanniainen, V., Kari, S., and Ylä-Liedenpohja, J., (2007), "Nordic Dual Income Taxation", International Tax and Public Finance", forthcoming.

[19] Kanniainen, V. and Panteghini, P., (2007), "Non-Neutral Effects of the Cash-Flow Tax, the ACE Tax and the Dividend tax", mimeo.

[20] Klapper, L., Laeven, L., and Rajan, R., (2006), "Entry Regulation as a Barrier to Entrepreneurship", Journal of Financial Economics, 82, 591-629.

[21] Lucas, R. Jr. (1978), "On The Size Distribution of Business Firms", Bell Journal of Economics, 9, 508 - 523.

[22] Mata, J. ja Portugal, P. (1994), Life Duration of New Firms", Journal of Industrial Economics, 42, 227-245.

[23] Myers, S.C. and Majluf, N.S. (1984), "Corporate Financing and Investment Decisions when Firms Have Information that Investors Do Not Have", Journal of Financial Economics, 13, 187-221.

[24] Nickel, S. (1997), "Unemployment and Labor Market Rigidities: Europe versus North America", Journal of Economic Perspectives, 35, 55-74.

[25] Oswald, A. (1985), "The Economic Theory of Trade Unions: An Introductory Survey", Scandinavian Journal of Economics, 87, 160 - 193.

[26] Parker, S., (2004), The Economics of Self-Employment and Entrepreneurship, Cambridge University Press.

[27] Perez-Gonzales, F. (2006), "Inherited Control and Firm Performance", The American Economic Review, 96,1559-1588. 
[28] Poutvaara, P. (2002), "Income Redistribution and Risky Occupational Choices", Topics in Economic Analysis 83 Policy 2(1), Article 8. Available at: http://www.bepress.com/bejeap/topics/vol2/iss1/art8.

[29] Puri, M., and Robinson, D.T., (2006), "Who are entrepreneurs and why do they behave that way?", A paper presented at the Recafe workshop, London, October 2007. 